Multidisciplinary Journal

Journal homepage: https://jurnal.unej.ac.id/index.php/multijournal

\title{
Analisis Kinerja SIMRS RSU Bhakti Husada Banyuwangi Menggunakan IT Balanced Scorecard dan Model for Mandatory Use of Software Technolgies
}

\author{
Performance Analysis of HMIS Bhakti Husada General Hospital Banyuwangi Using \\ IT Balanced Scorecard and Model for Mandatory Use of Software Technologies
}

\author{
Vivi Sefrinta Izza Afkarina ${ }^{1}$, Rudi Wibowo ${ }^{2}$, Saiful Bukhori ${ }^{3}$ \\ ${ }^{I}$ Pascasarjana Ilmu Kesehatan Masyarakat Unversitas Jember \\ ${ }^{2}$ Pascasarjana Ilmu Kesehatan Masyarakat Unversitas Jember \\ ${ }^{3}$ Pascasarjana Ilmu Kesehatan Masyarakat Unversitas Jember \\ vivi.sefrinta@gmail.com
}

\begin{abstract}
ABSTRAK. SIMRS adalah salah satu bentuk pemanfaatan teknologi kesehatan untuk mendukung keberhasilan manajamen dan peningkatan kualitas pelayanan di rumah sakit. Penerapan SIMRS akan bermanfaat jika penerapannya sesuai dengan visi, misi, dan tujuan rumah sakit dengan menetapkan strategi bisnis dan strategi sistem teknologi informasi. Tujuan penelitian ini adalah untuk menganalisis kinerja SIMRS RSU Bhakti Husada menggunakan IT Balanced Scorecard dan Model for Mandatory Use of Software Technologies. Penelitian ini menggunakan pendekatan kuantitatif cross sectional dengan jumlah sampel 45 responden pengguna SIMRS. Data diukur menggunakan indikator penilaian IT Balanced Scorecard dan dianalisis menggunakan SEM-PLS. Hasil penelitian menunjukkan bahwa kinerja SIMRS dikategorikan baik. Capaian kinerja SIMRS dengan IT Balanced Scorecard perspektif orientasi masa depan sebesar 83,3\% dan perspektif penyempurnaan operasional sebesar 100\%. Semua variabel Model for Mandatory Use of Software Technologies memiliki pengaruh yang signifikan terhadap implementasi SIMRS yaitu variabel kualitas informasi terhadap kepuasan informasi, kepuasan informasi terhadap kemudahan penggunaan, dan kemudahan penggunaan terhadap sikap.
\end{abstract}

Kata Kunci: SIMRS, IT Balanced Scorecard, Model for Mandatory Use of Software Technologies

ABSTRACT. HMIS is a form of utilizing health technology to support the success of management and improvement of service quality in hospitals. The implementation of HMIS will be beneficial if its implementation is in accordance with the vision, mission, and goals of the hospital by establishing a business strategy and information technology system strategy. The purpose of this study was to analyze the performance of HMIS Bhakti Husada Hospital using the IT Balanced Scorecard and the Model for Mandatory Use of Software Technologies. This study uses a cross sectional quantitative approach with a sample of 45 respondents using HMIS. The data measured using the IT Balanced Scorecard assessment indicators were analyzed using SEM-PLS. The results showed that the HMIS performance was categorized as good. The HMIS performance achievement with the IT Balanced Scorecard with a future orientation perspective is $83.3 \%$ and an operational improvement perspective is $100 \%$. All of the Model for Mandatory Use of Software Technologies variables have a significant influence of HMIS implementation, namely the information quality variable on information satisfaction, information satisfaction on ease of use, and ease of use on attitudes.

Keywords: SIMRS, IT Balanced Scorecard, Model for Mandatory Use of Software Technologies 


\section{Pendahuluan}

Ketersediaan data dan informasi, dukungan kemajuan ilmu pengetahuan dan teknologi kesehatan, dan dukungan hukum kesehatan dan administrasi kesehatan sangat memastikan keberhasilan manajemen kesehatan di rumah sakit ${ }^{[2]}$. SIMRS adalah salah satu bentuk pemanfaatan teknologi kesehatan untuk mendukung keberhasilan manajamen dan peningkatan kualitas pelayanan di rumah sakit. Ketersediaan SIMRS yang memiliki kemampuan komunikasi data, diharapkan implementasi SIMRS tidak hanya mampu meningkatkan dan mendukung pelayanan kesehatan di lingkup internal rumah sakit, tetapi juga dapat melakukan pertukaran data elektronik antar fasilitas pelayanan kesehatan. Sehingga dapat menyediakan informasi secara komprehensif dan berkesinambungan yang berkaitan dengan pasien dalam meningkatkan pelayanan ${ }^{[5]}$.

Pemanfaatan SIMRS di RSU Bhakti Husada telah diimplementasikan di seluruh unit dan terintegrasi antar satu unit dengan unit yang lain. Namun, pada pelaksanaannya masih terdapat beberapa kendala diantaranya 1) komunikasi data belum optimal, 2) terdapat modul yang belum terintegrasi, 3) luaran kebutuhan pelaporan belum terpenuhi, dan 4) terdapat kesalahan user dalam melakukan entry dan update data. Penerapan SIMRS akan bermanfaat jika penerapannya sesuai dengan visi, misi, dan tujuan rumah sakit dengan menetapkan strategi bisnis dan strategi sistem teknologi informasi. Sehingga dibutuhkan suatu suatu analisis berbagai faktor yang mempengaruhi terbentuknya suatu sistem informasi yang mampu beradaptasi dan selaras dengan strategi bisnis. Model penilaian Model for Mandatory Use of Software Technologies dipilih untuk menganalisis dari aspek pengguna dan IT Balanced Scorecard dari aspek capaian kinerja organisasi melalui pemanfaatan SIMRS.

IT Balanced Scorecard dapat digunakan mengukur kinerja organisasi tidak hanya diukur dari keuntungan yang diperoleh secara finansial saja, namun juga mempertimbangkan proses internal serta kepuasan dan peningkatan kompetensi dari setiap pegawai. Dengan demikian perusahaan tersebut dapat lebih memastikan kinerja yang baik bukan saja di masa kini namun juga di masa yang akan datang ${ }^{[1]}$. Secara umum tiap-tiap perspektif IT Balanced Scorecard memiliki ukuran dan target yang harus dicapai oleh sebuah organisasi yang diperoleh dari visi, misi, dan strategi organisasi. Dalam penelitian ini, Model for Mandatory Use of Software Technologies dipilih karena SIMRS merupakan aplikasi yang bersifat mandatory di RSU Bhakti Husada Banyuwangi. Penelitian ini menganalisis variabel-variabel Model for Mandatory Use of Software Technologies yang berpengaruh terhadap kesuksesan SIMRS di RSU Bhakti Husada
Banyuwangi, yaitu kualitas informasi, kepuasan informasi, kemudahan penggunaan, dan sikap ${ }^{[6]}$.

\section{Bahan dan Metode}

Penelitian ini merupakan penelitian kuantitatif dengan pendekatan cross sectional yang bertujuan untuk menganalisis kinerja SIMRS menggunakan IT Balanced Scorecard dan mengetahui determinan implementasi SIMRS di RSU Bhakti Husada berdasarkan kerangka Model for Mandatory Use of Software Technologies. Lokasi penelitian ini di RSU Bhakti Husada Banyuwangi. Populasi dalam penelitian ini adalah pengguna SIMRS RSU Bhakti Husada.

Populasi pada penelitian ini adalah 156 orang pengguna SIMRS di RSU Bhakti Husada Banyuwangi. Besar sampel untuk penelitian ini dapat dihitung dengan menggunakan rumus Lameshow, sebagai berikut :

$$
\mathrm{n}=\frac{\mathrm{N} \cdot \mathrm{Z}_{1-\alpha / 2}^{2} \cdot \mathrm{p} \cdot \mathrm{q}}{\mathrm{d}^{2}(\mathrm{~N}-1)+\mathrm{Z}^{2}{ }_{1-\alpha / 2 \cdot p \cdot q}}
$$

$$
\begin{array}{ll}
\mathrm{n} & : \text { ukuran sampel } \\
\mathrm{N} & : \text { ukuran populasi } \\
\mathrm{Z}^{2}{ }_{1-\alpha / 2} & : \text { nilai } \mathrm{Z} \text { pada derajat kemaknaan } \\
& (95 \%=1,96) \\
\mathrm{p} & : \text { perkiraan proporsi }(0.2) \\
\mathrm{q} & : 1-\mathrm{p} \\
\mathrm{d} & : \text { presisi absolut }(10 \%)
\end{array}
$$

Cara penghitungan sampel:

$$
\begin{aligned}
\mathrm{n} & =\frac{\mathrm{N} \cdot \mathrm{Z}^{2}{ }_{1-\alpha / 2} \cdot \mathrm{p} \cdot \mathrm{q}}{\mathrm{d}^{2}(\mathrm{~N}-1)+\mathrm{Z}^{2}{ }_{1-\alpha / 2} \cdot \mathrm{p} \cdot \mathrm{q}} \\
\mathrm{n} & =\frac{156 \cdot 1,96^{2} \cdot 0,2 \cdot(1-0,2)}{0,10^{2}(156-1)+1,96^{2} \cdot 0,2(1-0,2)} \\
\mathrm{n} & =44,29 \\
\mathrm{n} & =45
\end{aligned}
$$

Jadi, berdasarkan rumus tersebut diperoleh sampel penelitian sebesar 45 responden.

Penelitian ini menggunakan data primer dan data sekunder yang diperoleh dari wawancara, observasi, dan kuisioner yang diisi melalui google formulir. Analisis data yang digunakan dalam penelitian ini untuk menguji pengaruh antar variabel menggunakan bantuan program Partial Least Square (PLS) 3.0 dengan analisis SEM (Structural Equation Modelling). 


\section{Hasil dan Pembahasan}

\section{Identifikasi Tujuan Strategi, Ukuran Strategi dan Capaian Ukuran Strategi Perspektif IT Balanced Scorecard SIMRS}

Penyelarasan visi, misi dan strategi RS dengan visi, misi dan strategi Unit IT merupakan langkah pertama dalam membangun IT Balanced Scorecard. Penyelarasan tersebut ditunjukkan pada Gambar 1 berikut :

\begin{tabular}{|c|c|}
\hline $\begin{array}{l}\quad \text { Visi RS } \\
\text { Menjadi unit usaha } \\
\text { pelayanan } \\
\text { kesehatan } \\
\text { terkemuka di } \\
\text { Kabupaten } \\
\text { Banyuwangi }\end{array}$ & \begin{tabular}{lr}
\multicolumn{3}{c}{ Visi Unit IT } \\
Terwujudnya & SIMRS \\
yang kompeten dan \\
kompetitif r \\
keandalan pengelolaan \\
data dan sistem informasi \\
yang handal
\end{tabular} \\
\hline & \\
\hline $\begin{array}{l}\text { Misi RS } \\
\text { a. Menyelengarakan } \\
\text { pelayanan } \\
\text { kesehatan } \\
\text { bermutu dan } \\
\text { terpercaya. } \\
\text { b.Menyelengarakan } \\
\text { pengembangan } \\
\text { kualitas SDM } \\
\text { c. Menyediakan } \\
\text { sarana prasarana } \\
\text { yang lengkap dan } \\
\text { terintegrasi. } \\
\text { d.Memberikan nilai } \\
\text { tambah kepada } \\
\text { perusahaan, serta } \\
\text { kesejahteraan } \\
\text { kepada karyawan } \\
\text { dan pemangku } \\
\text { kepentingan }\end{array}$ & 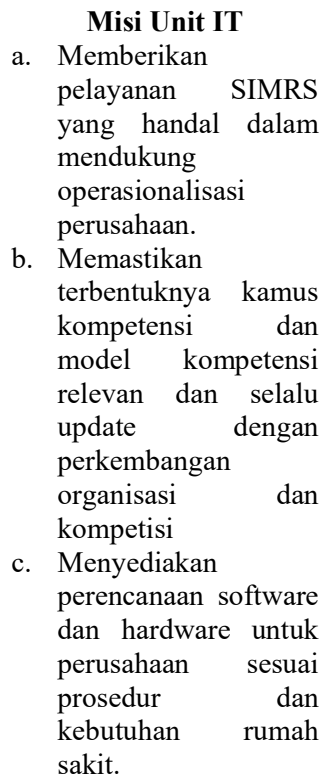 \\
\hline $\begin{array}{l}\text { Berpartisipasi } \\
\text { dalam } \\
\text { pembangunan } \\
\text { kesehatan } \\
\text { masyarakat demi } \\
\text { peningkatan } \\
\text { kualitas sumber } \\
\text { daya manusia } \\
\text { Indonesia secara } \\
\text { rohani dan jasmani }\end{array}$ & \begin{tabular}{llr}
\multicolumn{2}{c}{ Tujuan Strategis Unit } \\
a. & Mengembangkan \\
& modul aplikasi \\
& SIMRS untuk \\
mewujudkan sistem \\
manajemen yang \\
efektif dan efisien \\
b. Mengembangkan \\
infrastruktur SIMRS \\
untuk mendukung \\
peningkatan kualitas \\
SIMRS \\
c. Meningkatkan \\
kompetensi SDM \\
Unit IT dan \\
kompetensi pengguna \\
terkait SIMRS
\end{tabular} \\
\hline
\end{tabular}

Gambar 1. Visi, Misi dan Tujuan Strategi RS Dengan Visi, Misi dan Tujuan Strategis Unit IT
Demi terwujudnya SIMRS yang kompeten dan kompetitif serta keandalan pengelolaan data dan sistem informasi yang handal maka Unit IT berusaha mengembangkan dan mengelola SIMRS dalam mendukung pelayanan rumah sakit sehingga terwujudnya visi RSU Bhakti Husada Menjadi unit usaha pelayanan kesehatan terkemuka di Kabupaten Banyuwangi.

Dengan memberikan pelayanan SIMRS yang handal dalam mendukung operasionalisasi perusahaan dan menyediakan perencanaan software dan hardware untuk perusahaan sesuai prosedur dan kebutuhan rumah sakit, maka unit IT dapat mendukung rumah sakit dalam menyelengarakan pelayanan kesehatan bermutu dan terpercaya dan menyediakan sarana prasarana yang lengkap dan terintegrasi.

RSU Bhakti Husada berpartisipasi dalam pembangunan kesehatan masyarakat demi peningkatan kualitas sumber daya manusia Indonesia secara rohani dan jasmani. Untuk meningkatkan kualitas sumber daya manusia sebagai upaya pembangunan kesehatan masyarakat dalam bidang teknologi informasi dilakukan oleh unit IT melalui :

a. Mengembangkan modul aplikasi SIMRS untuk mewujudkan sistem manajemen yang efektif dan efisien

b. Mengembangkan infrastruktur SIMRS untuk mendukung peningkatan kualitas SIMRS

c. Meningkatkan kompetensi SDM Unit IT dan kompetensi pengguna terkait SIMRS

Setelah menyelaraskan visi, misi dan strategi RS dengan visi, misi dan strategi Unit IT, langkah selanjutnya yaitu menyelaraskan strategi Unit IT dengan 2 perspektif IT Balanced Scorecard. Penyelarasan tersebut bertujuan untuk memperoleh tujuan strategis yang sesuai dengan masing-masing strategi Unit IT.

Tabel 1. Menyelaraskan Strategi Unit IT Dengan Perspekti IT Balanced Scorecard

\begin{tabular}{|c|c|c|}
\hline $\begin{array}{c}\text { IT Balanced } \\
\text { Scorecard }\end{array}$ & Strategi & $\begin{array}{c}\text { Tujuan } \\
\text { Strategis }\end{array}$ \\
\hline $\begin{array}{l}\text { Perspektif } \\
\text { Penyempurnaan } \\
\text { Operasional }\end{array}$ & $\begin{array}{l}\text { a. Mengembangkan } \\
\text { modul aplikasi } \\
\text { SIMRS untuk } \\
\text { mewujudkan } \\
\text { sistem manajemen } \\
\text { yang efektif dan } \\
\text { efisien } \\
\text { b. Mengembangkan } \\
\text { infrastruktur } \\
\text { SIMRS untuk } \\
\text { mendukung } \\
\text { peningkatan } \\
\text { kualitas SIMRS }\end{array}$ & $\begin{array}{l}\text { Optimalisasi } \\
\text { pengemban } \\
\text { gan SIMRS }\end{array}$ \\
\hline $\begin{array}{l}\text { Perspektif } \\
\text { Orientasi } \\
\text { Masa Depan }\end{array}$ & $\begin{array}{l}\text { a. Mengembangkan } \\
\text { modul aplikasi } \\
\text { SIMRS untuk } \\
\text { mewujudkan sistem } \\
\text { manajemen yang } \\
\text { efektif dan efisien }\end{array}$ & $\begin{array}{l}\text { a. Peningkat } \\
\text { an } \\
\text { kualitas } \\
\text { staf Unit } \\
\text { IT }\end{array}$ \\
\hline
\end{tabular}




\begin{tabular}{|c|c|c|}
\hline $\begin{array}{c}\text { IT Balanced } \\
\text { Scorecard }\end{array}$ & Strategi & $\begin{array}{c}\text { Tujuan } \\
\text { Strategis }\end{array}$ \\
\hline $\begin{array}{l}\text { Perspektif } \\
\text { Orientasi } \\
\text { Masa Depan }\end{array}$ & $\begin{array}{l}\text { b. Mengembangkan } \\
\text { infrastruktur } \\
\text { SIMRS untuk } \\
\text { mendukung } \\
\text { peningkatan } \\
\text { kualitas SIMRS } \\
\text { c. Meningkatkan } \\
\text { kompetensi staf } \\
\text { Unit IT dan } \\
\text { kompetensi } \\
\text { pengguna terkait } \\
\text { SIMRS }\end{array}$ & $\begin{array}{l}\text { b. Peningkat } \\
\text { an jumlah } \\
\text { staf Unit } \\
\text { IT }\end{array}$ \\
\hline
\end{tabular}

\section{Analisis Hasil Pengukuran IT Balanced Scorecard}

Pengukuran IT Balanced Scorecard dilakukan dengan mengumpulkan data aktual RS. Setelah pengumpulan data dilakukan maka langkah selanjutnya yaitu melakukan perhitungan pencapaian terhadap sasaran dari masing-masing ukuran strategis.

A. Perspektif Penyempurnaan Operasional

Tabel 2. Hasil pengukuran perspektif penyempurnaan operasional

\begin{tabular}{clccc}
\hline $\begin{array}{c}\text { Tujuan } \\
\text { Strategis }\end{array}$ & $\begin{array}{l}\text { Ukuran } \\
\text { Strategis }\end{array}$ & Sasaran & $\begin{array}{c}\text { Kondisi } \\
\text { Aktual }\end{array}$ & $\begin{array}{c}\text { Capai } \\
\text { an }\end{array}$ \\
\hline A. Optimal & A.1 $\%$ & $100 \%$ & $100 \%$ & $100 \%$ \\
isasi & penambahan & $(2$ & $(2$ & \\
Pengem & hardware & paket) & paket) & \\
bangan & A.2\% & $100 \%$ & $100 \%$ & $100 \%$ \\
SIMRS & penambahan & $(2$ & $(2$ & \\
& software & paket) & paket) & \\
& (modul & & & \\
\hline \multicolumn{5}{c}{ SIMRS) } \\
\multicolumn{3}{c}{ Total } & & $200 \%$ \\
\hline \multicolumn{3}{c}{ Rata-rata } & $100 \%$ \\
\hline
\end{tabular}

Ditinjau dari hasil perspektif penyempurnaan operasional (Tabel 2) maka dapat dikatakan bahwa perspektif ini telah mencapai kinerja yang diharapkan dimana pencapaian secara keseluruhan yaitu sebesar 100\%. Capaian ini menunjukkan bahwa perspektif penyempurnaan operasional terpenuhi sesuai sasaran strategis unit IT. Penambahan hardware dan software yang dilakukan unit IT dalam rangka mengembakan dan memenuhi kebutuhan SIMRS telah tercapai sesuai dengan target rencana strategis periode 2019-2021. Penambahan software pada tahun 2019 adalah AMS (Aplikasi Manajemen Surat) dan JDIH (Jaringan Dokumentasi dan Informasi Hukum). Sedangkan pada tahun 2020 penambahan software SIMPEG (Sistem Informasi Pegawai) dan SILAM (Sistem Informasi Laporan Manajemen).

Hasil capaian penyempurnaan operasional menunjukkan bahwa unit IT berhasil dalam menjalankan bisnis internal yang dibutuhkan rumah sakit. Sehingga kebutuhan pengguna terpenuhi dan dapat berdampak pada efektivitas dan efisiensi pelayanan yang diberikan. Menurut Grembergen ${ }^{[4]}$ dalam jurnalnya yang dipublikasikan oleh ISACA Journal menyatakan bahwa perspektif penyempurnaan operasional memiliki misi untuk menghasilkan efektivitas dan efisiensi dari aplikasi dan layanan TI. Berdasarkan misi tersebut maka peran Unit IT mampu menghasilkan pelayanan terbaik yang efektif dan efisien dari aplikasi dan layanan SIMRS dapat dihasilkan yang pada akhirnya telah memberikan kontribusi yang nyata bagi RS.

B. Perspektif Orientasi Masa Depan

Tabel 3. Hasil pengukuran perspektif orientasi masa depan

\begin{tabular}{|c|c|c|c|c|}
\hline $\begin{array}{c}\text { Tujuan } \\
\text { Strategis }\end{array}$ & $\begin{array}{c}\text { Ukuran } \\
\text { Strategis }\end{array}$ & Sasaran & $\begin{array}{l}\text { Kondisi } \\
\text { Aktual } \\
\end{array}$ & $\begin{array}{c}\text { Capai } \\
\text { an }\end{array}$ \\
\hline $\begin{array}{l}\text { A. Peningk } \\
\text { atan } \\
\text { kualitas } \\
\text { staf } \\
\text { Unit IT }\end{array}$ & $\begin{array}{l}\text { A.1 } \\
\text { Jumlah } \\
\text { staf } \\
\text { dengan } \\
\text { latar } \\
\text { belakang } \\
\text { pendidikan } \\
\text { IT }\end{array}$ & $\begin{array}{c}100 \% \\
(3 \\
\text { orang) }\end{array}$ & $66,67 \%$ & $\begin{array}{c}66,67 \\
\%\end{array}$ \\
\hline $\begin{array}{ll}\text { B. } & \text { Penamb } \\
\text { ahan } \\
\text { jumlah } \\
\text { staf } \\
\text { Unit IT }\end{array}$ & $\begin{array}{l}\text { B.1 } \\
\text { jumlah } \\
\text { penambah } \\
\text { an staf }\end{array}$ & $\begin{array}{c}100 \% \\
(1 \\
\text { orang) }\end{array}$ & $100 \%$ & $100 \%$ \\
\hline \multicolumn{4}{|c|}{ Total } & $166,6 \%$ \\
\hline \multicolumn{4}{|c|}{ Rata-rata } & $83,3 \%$ \\
\hline
\end{tabular}

Ditinjau dari hasil perbandingan perspektif orientasi masa depan (Tabel 3) menunjukkan bahwa pencapaian perspektif ini yaitu 83,3\%. Belum optimalnya capaian sasaran yang diharapkan dikarenakan belum terpenuhinya jumlah staf Unit IT yang berlatar belakang pendidikan teknologi informasi, teknologi komputer, sistem informasi, dll. Namun, penambahan staf pada periode renstra 20192021 sudah terpenuhi dengan adanya penambahan 1 staf IT pada tahun 2019. Staf IT saat ini 1 staf berlatar belakang S1 Sistem Informasi dan 1 staf dengan latar belakang D3 Manajamen Komputer.

Strategi pada perspektif orientasi masa depan untuk menjadi pembelajaran dan pertumbuhan rumah sakit yang lebih baik adalah pentingnya untuk mengevaluasi kinerja manajemen terhadap kualitas pemanfaatan dam pengembangan SIMRS. Implementasi SIMRS yang baik berdampak pada kepuasan seluruh staf rumah sakit, produktivitas kerja, dan mampu melaksanakan operasionalisasi SIMRS yang optimal dengan sumber daya manusia terbatas yang kompeten. Sehingga rumah sakit mampu memanfaatkan teknologi dan beradaptasi untuk menjawab tantangan masa depan. Adapun strategi untuk mencapai kinerja penyempurnaan operasional secara optimal dapat dilakukan dengan upaya sebagai berikut ${ }^{[4]}$ :

1) Pelatihan dan pendidikan bagi staf TI

2) Keahlian staf TI

3) Mengkaji teknologi yang ada

4) Menyimpan portofolio aplikasi 
Tujuan strategis pada perspektif orientasi masa depan dalam penelitian ini sesuai dengan strategi yang dibuat oleh Grembergen ${ }^{[4]}$ yaitu peningkatan kualitas staf dari sisi latar belakang pendidikan. Dengan terpenuhinya kualitas staf dari sisi latar belakang pendidikan dan jumlah staf yang memadai maka akan dapat membawa Unit IT bekerja lebih optimal dalam mengembangkan SIMRS dan membawa SIMRS menjadi salah satu motor dalam mewujudkan tujuan RS.

\section{Analisis Data Pengukuran Model for Mandatory Use of Software Technologies}

Analisis PLS terdiri dari dua tahap, yaitu outer model dan inner model. Pengujian yang dilakukan meliputi pengujian validitas (validitas konvergen dan validitas diskriminan) dan pengujian reliabilitas.

\section{Validitas Konvergen}

Untuk exploratory research nilai loading factor harus memiliki nilai $>0.05$. Loading factor merupakan besaran korelasi antara indicator dengan variabel latennya. Pada Tabel 3 dapat dilihat hasil dari loading factor untuk setiap indicator yang dimiliki masing-masing varaibel. Selain itu validitas konvergen juaga melihat nilaiu AVE (average variance extracted) dengan nilai $>0,7$. Tabel 2 menunjukkan nilai AVE variabel penelitian. Tabel 4. Hasil Uji Validitas Konvergen

\begin{tabular}{llcc}
\hline \multirow{4}{*}{ Variabel } & Indikator & $\begin{array}{c}\text { Loading } \\
\text { Factor }\end{array}$ & Keterangan \\
\hline \multirow{4}{*}{$\begin{array}{l}\text { Kualitas } \\
\text { Informasi }\end{array}$} & KI_1 & 0,922 & Valid \\
\cline { 2 - 4 } & KI_2 & 0,955 & Valid \\
\cline { 2 - 4 } & KI_3 & 0,936 & Valid \\
\cline { 2 - 4 } KI_4 & 0,925 & Valid \\
\hline \multirow{2}{*}{ Infopuasan } & KI_5 & 0,872 & Valid \\
\cline { 2 - 4 } Kemusi 1 & KPI_2 & 0,974 & Valid \\
\cline { 2 - 4 } penggunaan & KPI_3 & 0,974 & Valid \\
\cline { 2 - 4 } & KP_1 & 0,897 & Valid \\
\cline { 2 - 4 } & KP_2 & 0,908 & Valid \\
\cline { 2 - 4 } & KP_3 & 0,957 & Valid \\
\hline \multirow{3}{*}{ Sikap } & S_1 & 0,926 & Valid \\
\cline { 2 - 4 } & S_2 & 0,936 & Valid \\
\cline { 2 - 4 } & S_3 & 0,970 & Valid \\
\cline { 2 - 4 } & S_4 & 0,932 & Valid \\
\hline
\end{tabular}

Tabel 5. Nilai AVE

\begin{tabular}{ll}
\hline \multicolumn{1}{c}{ Variabel } & AVE \\
\hline Kualitas Informasi & 0.851 \\
Kepuasan Informasi & 0,901 \\
Kemudahan penggunaan & 0,873 \\
Sikap & 0,887 \\
\hline
\end{tabular}

\section{Validitas Diskriminan}

Tabel 6 menunjukkan nilai akar kuadrat AVE variabel lebih besar daripada nilai yang lain (ditunjukkan dengan angka yang dicetak tebal pada garis diagonal). Pengujian validitas diskriminan ini menandakan bahwa seluruh variabel memiliki discriminant validity yang tinggi.

Tabel 6. Hasil Uji Validitas Diskriminan

\begin{tabular}{lcccc}
\hline & KP & KPI & KI & S \\
\hline KP & $\mathbf{0 , 9 0 8}$ & & & \\
KPI & 0,877 & $\mathbf{0 , 9 7 4}$ & & \\
KI & 0,803 & 0,881 & $\mathbf{0 , 9 2 2}$ & \\
S & 0,856 & 0,882 & 0,650 & $\mathbf{0 , 9 3 6}$ \\
\hline
\end{tabular}

\section{Composite Reliability}

Reliabilitas diukur dengan melihat nilai composite reliability atau cronbachs alpha. Nilai composite reliability harus $>0,7^{[3]}$. Nilai uji reliabilitas dapat dilihat pada Tabel 7 berikut :

Tabel 7. Nilai crobanch alpha dan composite reliability

\begin{tabular}{lcc}
\hline \multicolumn{1}{c}{ Variabel } & $\begin{array}{c}\text { Cronbach's } \\
\text { Alpha }\end{array}$ & $\begin{array}{c}\text { Composite } \\
\text { Reliability }\end{array}$ \\
\hline Kualitas Informasi & 0,956 & 0,851 \\
\hline Kepuasan Informasi & 0,944 & 0,901 \\
\hline $\begin{array}{l}\text { Kemudahan } \\
\text { Penggunaan }\end{array}$ & 0,952 & 0,873 \\
\hline Sikap & 0,958 & 0,887 \\
\hline
\end{tabular}

\section{Model Struktural}

Inner model (model struktural) merupakan pola hubungan antar variabel penelitian. Evaluasi terhadap model struktural dengan melihat koefisien antar variabel dan nilai koefisien determinasi $R$ square (R2). Nilai R2 dibagi menjadi 3 klasifikasi yaitu kuat $(0,67)$, moderat $(0,33)$, dan lemah $(0,19)^{[3]}$. Nilai R square (R2) dapat dilihat pada tabel berikut.

Tabel 8. Nilai $\mathrm{R}^{2}$ variabel penelitian

\begin{tabular}{lc}
\hline \multicolumn{1}{c}{ Variabel } & Adjusted R Square \\
\hline Kualitas Informasi & - \\
\hline Kepuasan Informasi & 0.813 \\
\hline Kemudahan penggunaan & 0.693 \\
\hline Sikap & 0.721 \\
\hline
\end{tabular}

Berdasarkan tabel 8 dapat diinterpretasikan bahwa R2 adalah variabel independent atau variabel yang tidak dipengaruhi oleh variabel lain. Sementara itu variabel kepuasan informasi mempunyai nilai R2 sebesar 0.813 sehingga dapat diinterpretasikan bahwa variabel kepuasan informasi dapat dijelaskan oleh variabel kualitas informasi $81,3 \%$ sedangkan sisanya dijelaskan oleh variabel lainnya yang tidak termasuk dalam model ini. Dengan nilai R2 sebesar $81,3 \%$ maka model ini termasuk kategori model yang kuat.

Variabel kemudahan penggunaan mempunyai nilai R2 sebesar 0,693 sehingga dapat diinterpretasikan bahwa variabel kemudahan penggunaan dapat dijelaskan oleh variabel kepuasan informasi sebesar $69,3 \%$ sedangkan sisanya dijelaskan oleh variabel lain yang tidak termasuk dalam model ini. Dengan nilai R2 sebesar 69,3\% maka model ini termasuk kategori model yang kuat. Variabel sikap mempunyai nilai R2 sebesar 0,721 sehingga dapat diinterpretasikan bahwa variabel 
sikap dapat dijelaskan oleh variabel kepuasan informasi sebesar $72,1 \%$ sedangkan sisanya dijelaskan oleh variabel lain yang tidak termasuk dalam model ini. Dengan nilai R2 sebesar 72,1\% maka model ini termasuk kategori model yang kuat.

Analisis Variabel-Variabel Model for Mandatory Use of Software Technologies yang Berpengaruh terhadap Kesuksesan SIMRS

Pengujian hipotesis dilakukan dengan metode bootstrapping. Data dianalisis dengan tingkat signifikansi $(\alpha)=5 \%$ dan tingkat kepercayaan $95 \%$. Nilai $\mathrm{T}$ tabel dengan tingkat signifikansi 0,05 dan derajat kebebasan $(\mathrm{df})=(\mathrm{n}-1)=(45-1)=45$ untuk hipotesis satu ekor (one-tailed) adalah 1,66. Apabila nilai $\mathrm{T}$ statistik $>$ nilai $\mathrm{T}$ tabel, maka pengaruh antara satu variabel dengan variabel yang lain signifikan dan berlaku sebaliknya. Selain dengan melihat nilai $\mathrm{T}$, dapat juga dengan melihat $\mathrm{P}$ value. Apabila $\mathrm{P}$ value $\leq$ nilai $\alpha=0,05$ maka pengaruh antara satu variabel dengan variabel yang lain signifikan dan berlaku sebaliknya.

Tabel 9. Uji hipotesis

\begin{tabular}{lllcccc}
\hline \multirow{2}{*}{ Hipotesis } & \multicolumn{2}{c}{ Jalur } & Kofisiensi & T & P & Kesimpulan \\
\cline { 2 - 3 } & \multicolumn{1}{c}{ Dari } & \multicolumn{1}{c}{ Ke } & Jalur & Statistik & value & Kepuasan informasi \\
K1 & Kualitas Informasi & 0.904 & 23.165 & 0,000 & $\mathrm{H}_{1}$ Diterima \\
H2 & Kepuasan Informasi & Kemudahan penggunaan & 0.836 & 12,914 & 0,000 & $\mathrm{H}_{1}$ Diterima \\
H3 & Kemudahan penggunaan & Sikap & 1.091 & 2,629 & 0,009 & $\mathrm{H}_{1}$ Diterima
\end{tabular}

Hasil pengujian hipotesis pertama ditunjukkan pada Tabel 7. Nilai T Statistik $>\mathrm{T}$ tabel $(23.165>1.66)$ atau nilai $P$ value $\leq a \quad(0,000 \leq$ $0,05)$, menunjukkan kualitas informasi berpengaruh signifikan terhadap kepuasan informasi dengan koefisien jalur sbesar 0.904. Hasil ini sesuai dengan penelitian Koh et $\mathrm{al}^{[6]}$ yang menyatakan semakin tinggi kualitas informasi, maka kepuasan informasi akan semakin tinggi. Kualitas informasi yang dihasilkan SIMRS di RSU Bhakti Husada sesuai dengan kebutuhan responden dan real time sehingga pengguna puas dalam menggunakan SIMRS sebagai tools yang mendukung dalam menyelesaikan pekerjaan sehari-hari. Hasil ini sesuai dengan penelitian Koh et. $\mathrm{al}^{[6]}$ yang menyatakan semakin tinggi kualitas informasi, maka kepuasan informasi akan semakin tinggi. Jika informasi yang dihasilkan dari suatu sistem informasi berkualitas, maka akan meningkatkan kepuasan pengguna terhadap informasi yang diterima. Informasi yang dihasilkan oleh SIMRS membantu pengguna dalam melaksanakan pekerjaan sehari-hari.

Hasil pengujian hipotesis kedua, nilai $\mathrm{T}$ Statistik $>\mathrm{T}$ tabel $(12.914>1.66)$ atau nilai $\mathrm{P}$ value $\leq a(0,000 \leq 0,05)$, menunjukkan kepuasan informasi berpengaruh signifikan terhadap kemudahan penggunaan dengan koefisien jalur sbesar 0.836. Dengan kata lain, terdapat pengaruh kepuasan informasi terhadap kemudahan penggunaan pada kesuksesan SIMRS. Desain SIMRS yang berbasis desktop dan dikembangkan sendiri oleh tim IT membuat responden puas dalam menggunakan SIMRS sehingga SIMRS mudah untuk digunakan dalam menyelesaikan pekerjaan sesuai harapan pengguna. Hasil ini sesuai dengan penelitian Mitropoulus ${ }^{[7]}$ jika informasi yang dihasilkan berkualitas, maka akan meningkatkan kepuasan pengguna terhadap infromasi yang didapat. Semakin tinggi kepuasan informasi maka secara langsung kemudahan penggunaan pengguna terhadap sistem akan semakin tinggi. Informasi yang dihasilkan SIMRS dapat dianalisis sesuai dengan kebutuhan penggunannya. Informasi tersebut membantu mempermudh dan mempercepat pekerjaan, serta meningkatkan produktivitas.

Hasil pengujian hipotesis ketiga, nilai $\mathrm{T}$ Statistik $>$ T tabel $(2.629>1.66)$ atau nilai $\mathrm{P}$ value $\leq$ a $(0,009 \leq 0,05)$, menunjukkan kemudahan penggunaan berpengaruh signifikan terhadap sikap dengan koefisien jalur sbesar 1.091. Dengan kata lain, terdapat pengaruh kemudahan penggunaan terhadap sikap pada kesuksesan SIMRS. Mudahnya penggunaan SIMRS dalam membantu menyelesaikan tugas sehari-hari memberikan dampak perubahan sikap petugas untuk selalu memanfaatkan/ menggunakan SIMRS dalam memberikan pelayanan maupun mendokumentasikan pelayanan yang telah dilakukan. Hasil ini sesuai dengan penelitian Koh et $\mathrm{al}^{[6]}$ kemudahan penggunaan merupakan faktor yang membentuk sikap positif terhadap sistem informasi. Responden yakin dengan menggunkan SIMRS akan meningktakan kinerja. Selain membentuk sikap positif penggunaan aplikasi SIMRS, kemudahan yang ditawarkan dalam penggunaan aplikasi SIMRS akan memunculkan sikap positif. Sikap positif akan memberikan afirmasi positif, sehingga membantu pengguna dalam penggunaan SIMRS pada stiap pelayanan yng diberkan kepada pasien. Sikap tersebut didasari dengan keyakinan bahwa SIMRS membantu meninigkatkan kinerja pengguna

\section{Kesimpulan}

Kesimpulan yang dapat diambil dari penelitian ini adalah kinerja SIMRS RSU Bhakti Husada Banyuwangi dikategorikan baik. Hasil Kajian Capaian Kinerja SIMRS berdasarkan perspektif IT Balanced Scorecard menunjukan bahwa orientasi masa depan mendapat kategori 
dengan capaian sebesar $83,3 \%$ dan perspektif penyempurnaan operasional capaiannya sangat baik sebesar 100\%. Hasil uji variabel Model for Mandatory Use of Software Technologies menunjukkan bahwa semua variabel memiliki pengaruh yang signifikan terhadap kesuksesan implementasi SIMRS yaitu variabel kualitas informasi (KI) terhadap kepuasan informasi (KPI), kepuasan informasi (KPI) terhadap kemudahan penggunaan (KP), dan kemudahan penggunaan (KP) terhadap sikap $(\mathrm{S})$.

\section{Saran}

Berdasarkan hasil kajian IT Balanced Scorecard dan Model for Mandatory Use of Software Technologies, peneliti memberikan rekomendasi agar RSU Bhakti Husada:

a) melakukan evaluasi kinerja manajemen terhadap kualitas pemanfaatan dam pengembangan SIMRS,

b) pembuatan manual book SIMRS dan sosialisasi melalui pemberian pelatihan SIMRS secara periodik

c) analisis kebutuhan masing-masing unit terkait pengembangan SIMRS dan analisis beban kerja unit IT

Sehingga diharapkan SIMRS RSU Bhakti Husada mampu mengimplementasikan IT Good Governance berdasarkan Permenkes 82 Tahun 2013 tentang
SIMRS dan mewujudkan visi misi menjadi unit pelayanan kesehatan terkemuka di wilayah Banyuwangi.

\section{Referensi}

[1] Arofah, N., Sholiq, \& Nisafani, A. S. (2012). Penyusunan IT Balanced Scorecard untuk Pengukuran Kinerja Divisi IT di PT. Pertamina UPMS V Surabaya. Jurnal Teknik Pomits , 1 (2), 1 - 9

[2] Departemen Kesehatan Republik Indonesia. 2004. Sistem Kesehatan Nasional. Diakses dari : https://agus34drajat.files.wordpress.com/2010/10/sistemkesehatan-nasional.pdf

[3] Ghozali, I., \& Latan, H. 2015. Partial Least Squares: Konsep, Teknik, dan Aplikasi Mengguna- kan Program SmartPLS 3.0. Semarang: Badan Penerbit Universitas Diponegoro

[4] Grembergen, W.V. 2000. The balanced scorecard and IT governance. ISACA Journal. $2 . \quad 1-6$ https://www.isaca.org/Certification/CGEIT-Certified-in-theGovernance-of-Enterprise-IT/Prepare-for-the-Exam/StudyMaterials/Documents/The-Balanced-Scorecard-and-ITGovernance.pdf

[5] Kaelber, D. C. dan D. W. Bates. 2007. Health Information Exchange And Patient Safety. Journal of Biomedical Informatics. 40(2007). S40-S45. http://www.sciencedirect.com/science/article/pii/S1532046407 000901

[6] Koh, C.E., et. al. 2010. "A Model for Mandatory Use of Software Technologies: An Integrative Approach by Applying Multiple Levels of Abstraction of Informing Science." The Internaional Journal of an Emerging Transdicipline 13

[7] Mitropoulos, I. 2014. Management Information Systems in the Health Sector: Evidence of Mandatory Use. INFOCOMP : 51-53; 